\title{
Deep submarine groundwater discharge indicated by pore water chloride anomalies in the Gulf of Gdańsk, southern Baltic Sea
}

\author{
Beata Szymczycha ${ }^{1}$, Żaneta Kłostowska ${ }^{1,2}$, Karol Kuliński ${ }^{1}$, Aleksandra Winogradow ${ }^{1}$, \\ Jaromir Jakacki ${ }^{1}$, Zygmunt Klusek ${ }^{1}$, Miłosz Grabowski ${ }^{1}$, Aleksandra Brodecka-Goluch ${ }^{2}$, \\ Bożena Graca ${ }^{2}$, Marcin Stokowski ${ }^{1}$, Katarzyna Koziorowska ${ }^{1}$, Daniel Rak ${ }^{1}$ \\ ${ }^{1}$ Institute of Oceanology, Polish Academy of Sciences, Powstańców Warszawy 55, 81-712 \\ Sopot, Poland \\ ${ }^{2}$ Institute of Oceanography, University of Gdańsk, Al. Marszałka Piłsudskiego 46, 81-378 \\ Gdynia, Poland
}

\section{INTRODUCTION}

Submarine groundwater discharge (SGD) is a significant pathway for material transport to the coastal zone (Burnett et al. 2006). For some elements and isotopes SGD has been thought to be the principal source (Lin et al. 2010). Therefore, the interest in coastal groundwater flow systems has increased rapidly during the last decades. Most of the studies have been focused on shallow $(<20 \mathrm{~m})$, narrow zone $(<5 \mathrm{~km})$ along the coastline (Lin et al. 2010). Interestingly, some deep seafloor studies (Wilson 2005; Lin et al. 2010) indicated that SGD can occur a long distance from the shoreline $(\sim 25 \mathrm{~km})$. In the Baltic Sea SGD has been mainly investigated in the southern part primarily at coastal zones demonstrating that groundwater seepage is comparable to river loads in case of selected chemical substances (Piekarek- Jankowska 1994; Schlüter et al. 2004; Szymczycha et al. 2012; 2014; 2016). In this study we identified deep SGD located at acoustically turbid sediments in the Gulf of Gdańsk ( $\sim 70 \mathrm{~km}$ from the shore). Given the significance of benthic nutrients dynamics and sediment biogeochemical processes implications for the Baltic Sea environment, such as eutrophication, hypoxic and anoxic events, we aim to characterize the potential role of deep SGD in the Baltic Sea cycles of elements.

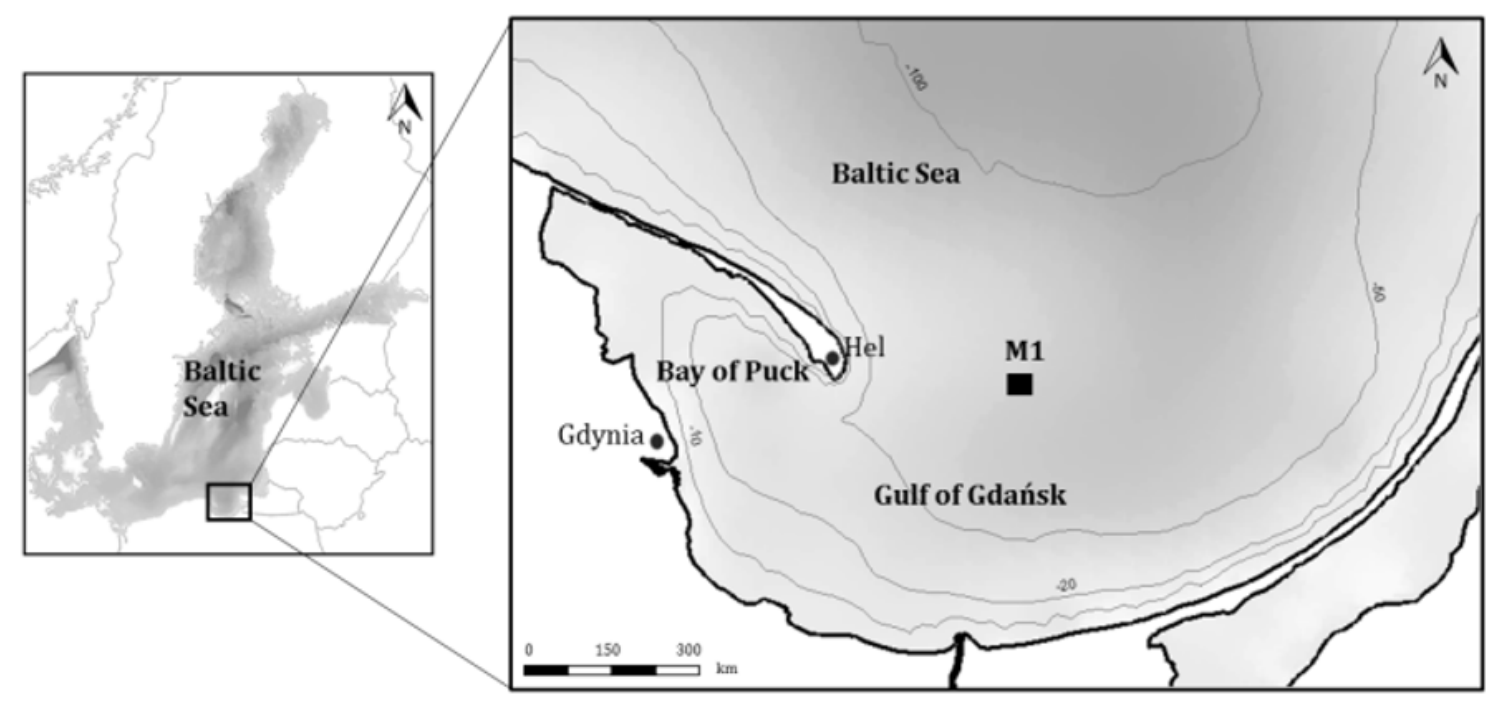

Figure 1. Location of the study area (M1). 


\section{METHODS}

The study area is located in the Gulf of Gdańsk, southern Baltic Sea (Fig.1). Sea water, pore water and sediments samples were collected on board the R/V Oceania during three cruises in May 2015, January 2017 and May 2017. Seawater salinity and temperature was retrieved from CTD files while sediment cores were collected by the Gemax gravity corer. Additionally acoustic observations of the sediments were made in order to detect gas distribution. In collected sediment samples water content, calcium $(\mathrm{Ca})$, total organic (TOC) and inorganic carbon (IC) were analyze while in collected pore water samples nutrients $\left(\mathrm{PO}_{4}{ }^{3-}, \mathrm{NO}_{3}{ }^{-}+\mathrm{NO}_{2}{ }^{-}, \mathrm{NH}_{4}{ }^{+}\right)$, dissolved organic carbon (DOC), dissolved inorganic carbon (DIC), metals ( $\mathrm{Na}, \mathrm{K}, \mathrm{Mg}, \mathrm{Ca}, \mathrm{Al}, \mathrm{Mn}, \mathrm{Fe}, \mathrm{Ni}, \mathrm{Cr}, \mathrm{Cu}, \mathrm{Cd}, \mathrm{Co}, \mathrm{Pb}$ ) and alkalinity were analyzed. Parameters such as ORP, $\mathrm{pH}$ and salinity were measured in situ. The SGD rate was based on numerical modelling.

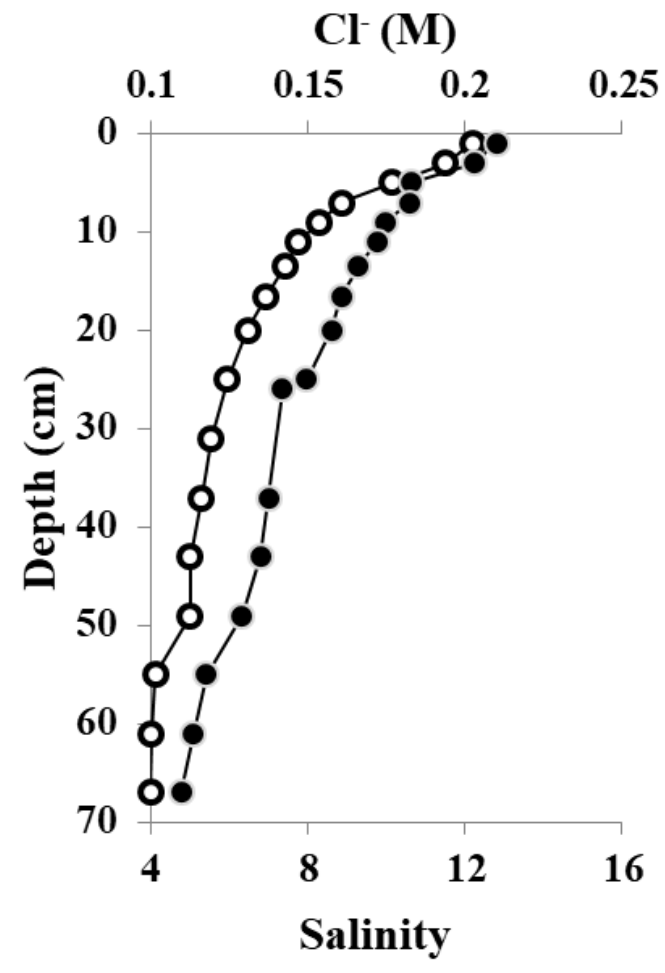

Figure 2. Examples of pore water depth profiles for chloride (hollow symbols) and salinity (solid symbols) in the study area.

\section{RESULTS AND DISCUSSION}

Seawater salinity, temperature and density were typical of the seasons when the samples were taken. The pore water depth profiles for both salinity and chloride significantly decreased with depth during every sampling campaign indicating freshwater source. The exemplary profiles are presented at Figure 2. The pore water concentrations of the main cations such as $\mathrm{Na}, \mathrm{Ca}, \mathrm{Mg}, \mathrm{K}$ showed similar trend to chloride. Generally, pore water profiles for $\mathrm{Cl}$, $\mathrm{Na}, \mathrm{Ca}, \mathrm{Mg}$ and, $\mathrm{K}$, unaffected by freshwater, are constant or increase linearly with depths (Carman and Rahm 1997; Schlüter et al. 2004). The curvature profiles are characteristic for areas affected by fluid flow, in this case SGD (Schlüter et al. 2004). The general pore water trend of DIC, DOC, trace elements, $\mathrm{PO}_{4}{ }^{3-}, \mathrm{NH}_{4}{ }^{+}$, TDS and alkalinity are comparable to those observed in deep sea anaerobic sediments. Interestingly, in the 
deepest layers of pore water increased concentrations of $\mathrm{Mn}, \mathrm{Fe}, \mathrm{Al}, \mathrm{PO}_{4}{ }^{3-}, \mathrm{NH}_{4}{ }^{+}, \mathrm{DIC}, \mathrm{DOC}$ and alkalinity were observed most probably due to groundwater seepage.

The calculated SGD rates ranged from 0.3 to $0.7\left(\mathrm{~L} \mathrm{~m}^{-2} \mathrm{~d}^{-1}\right)$. Comparable results were observed in the coastal area of the Eckernförde Bay, western Baltic Sea, where beside groundwater seepage, increased methane production and consequently methane release from sediments were detected (Schlüter et al. 2004). In our study area the sediments acoustic disturbance has been previously correlated with methane presence (Brodecka et al. 2013) while in the neighboring Bay of Puck, inner part of the Gulf of Gdańsk SGD occurrence was accompanied by methane and increased P, Si and DOC fluxes (Donis et al. 2017).

\section{CONCLUSIONS}

In this study we identified deep SGD located at acoustically turbid sediments in the Gulf of Gdańsk ( $\sim 70 \mathrm{~km}$ from the shore). The main impacts of the anoxic deep SGD are increased efflux of chemical substances such as $\mathrm{PO}_{4}{ }^{3-}, \mathrm{NH}_{4}{ }^{+}$, DIC, DOC, trace elements (Mn, Fe, $\mathrm{Al}$ ) and possibly methane. Therefore, SGD may significantly change their distribution both within the sediments and at the water-sediment interface.

\section{ACKNOWLEDGMENTS}

The results were obtained within the framework of the following projects: 2016/21/B/ST10/01213 sponsored by National Science Center and WaterPUCK financed by the National Centre for Research and Development (NCBR) within BIOSTRATEG program.

\section{REFERENCES}

Burnett, W.C., Aggarwal, P.K., Aureli, A., Bokuniewicz „H.J., Cable, J.E., Charette, M.A., Kontar, E., Krupa, S., Kulkarni, K.M., Loveless, A., Moore, W.S., Oberdorfer, J.A., Oliveira, J., Ozyurt, N., Povinec, P., Privitera, A.M.G., Rajar, R., Ramessur, R.T., Scholten, J., Stieglitz, T., Taniguchi, M., Turner, J.V. 2006. Quantifying submarine groundwater discharge in the coastal zone via multiple methods. Science of the Total Environment, 367, 498-543.

Carman, R., Rahm, L. 1997. Early diagenesis sediments in and chemical characteristics of interstitial water and the deep deposition bottoms of the Baltic proper. J. Sea Res. 37, 25-47.

Donis, D., Janssen, F., Wenz, F., Dellwig, O, Escher, P., Spitzy, A., M.E. Böttcher, 2017. Biogeochemical impact of submarine ground water discharge on coastal surface sands of the southern Baltic Sea. Estuar Coast Shelf S 189, 131- 142.

Lin, T-I, Wang, C-H, You, C-F, Huang, K-F, Chen, Y-G 2010. Deep submarine groundwater discgage indicated by tracers of oxygen, strontium isotopes an barium content in the Pingtung coastal zone southern Taiwan Mar Cem 122, 51-58.

Piekarek-Jankowska H., Matciak M., Nowacki J. (1994) Salinity variations as an effect of groundwater seepage through the seabed (Puck Bay. Poland), Oceanologia, 36, 33-46.

Schlüter M., Sauter E.J., Andersen C.A., Dahlgaard H., Dando P.R., 2004. Spatial distribution and budget for submarine groundwater discharge in Eckernförde Bay (Western Baltic Sea). Limnol. Oceanogr. 49, 157-167.

Szymczycha B., Vogler S., Pempkowiak J. (2012) Nutrient fluxes via submarine groundwater discharge to the Bay of Puck, Southern Baltic, Sci. Total Environ., 438, 86-93. 
Szymczycha, B., Maciejewska, A., Winogradow, A., Pempkowiak, J. 2014. Could submarine groundwater discharge be a significant carbon source to the southern Baltic Sea? In Oceanologia, 56, $327-347$.

Szymczycha, B., Kroeger, K. D., Pempkowiak, J. 2016. Significance of groundwater discharge along the coast of Poland as a source of dissolved metals to the southern Baltic Sea, Marine Pollution Bulletin, 109, 151-162.

Wilson, A.M. 2005. Fresh and saline groundwater discharge to the ocean : A regional perspective. Water Resour Res 41, WO2016.

Contact Information: Beata Szymczycha, Institute of Oceanology, Polish Academy of Sciences, Powstańców Warszawy 55, 81-712 Sopot, Poland, Phone: +48 (58) 7311738: beat.sz@iopan.gda.pl 